\title{
Influence of primary composition and diagenetic mineralization on natural gamma-ray and density logs of Carboniferous sandstones of the Dęblin Formation
}

\author{
Sara WRÓBLEWSKA ${ }^{1, *}$ and Małgorzata KOZŁOWSKA ${ }^{1}$ \\ 1 University of Warsaw, Faculty of Geology, Żwirki i Wigury 93, 02-089 Warszawa, Poland
}

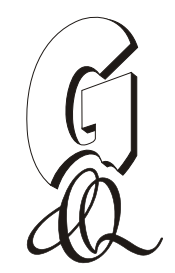

Wróblewska, S., Kozłowska, M., 2019. Influence of primary composition and diagenetic mineralization on natural gamma-ray and density logs of Carboniferous sandstones of the Dęblin Formation. Geological Quarterly, 63 (4): 741-756, doi: 10.7306/gq.1498

Associate editor: Jacek Szczepański

The Carboniferous sandstone of the Dęblin Formation is one of the targets for the petroleum industry in the Lublin Basin in southeastern Poland. The formation's primary and diagenetic composition makes it difficult to estimate its reservoir properties. Based on a detailed analysis of core and petrographic samples, normalization of gamma-ray and density logs was made with respect to the grain-framework of the rock. Recounted logs were used for distinguishing 4 different sandstone petrofacies. For these petrofacies, ranges of gamma-ray and bulk density values were determined and the impact of primary and diagenetic mineral composition was estimated. The application of this petrofacies method can upgrade the level of reservoir characterization and support the interpretation of uncored intervals.

Key words: petrofacies analysis, gamma-ray log, density log, diagenetic mineralization, Dęblin Formation, Lublin Basin.

\section{INTRODUCTION}

The Dęblin Formation is a part of the Carboniferous paralic-limnic succession of the Lublin Basin infill (Żelichowski 1972; Porzycki, 1988; Porzycki and Zdanowski, 1995; Waksmundzka, 1998, 2010, 2012, 2013). Due to the high sandstone content, the Dęblin Formation has become one of the targets for the petroleum industry in Poland. The first hydrocarbon discoveries in the Upper Carboniferous were made in 1976 in Minkowice, with a potential reservoir of $20 \times 10^{6} \mathrm{~m}^{3}$ of gas (Botor et al., 2002; Karnkowski, 2007).

The clastic rocks of the Dęblin Formation are composed mainly of quartz with a small amount of feldspars and lithic grains (Kozłowska, 2003, 2004, 2009). The lower part of the Dęblin Formation is commonly distinguished as the "silver sandstones" - the informal lithostratigraphic unit, which has a significant admixture of muscovite (Porzycki, 1988). Based on their mineralogical composition, these Carboniferous sandy rocks can be classified as quartz- and subarkosic arenites (Kozłowska, 2003, 2009). However, the high amount of matrix, mainly composed of kaolinite, illite, mixed-layered illite-smectite and Fe-chlorites causes that some of the sandy rocks are classified as wackes. The significant content of clay minerals and

\footnotetext{
* Corresponding author, e-mail: sara.wroblewska@student.uw.edu.pl
}

Received: March 13, 2019; accepted: August 26, 2019; first published online: December 3, 2019 the diagenetic cements (e.g., quartz, siderite and pyrite) also have a strong impact on the reservoir properties, especially the effective porosity and permeability (Kozłowska, 2003, 2004, 2009; Jarzyna and Bała, 2005).

Both primary cementation by quartz and siderite, and secondary burial dissolution of detrital grains and/or recrystallization into clay minerals are responsible for the strong differentiation of reservoir parameters across the Lublin Basin (Jarzyna and Bała, 2005; Kozłowska, 2009, 2011). A wide range of porosity (from 0.36 to $22.8 \%$ ) and a tendency of its reduction with depth has been observed in the rocks of the northwestern part of the basin (Kozłowska, 2003). In the central part of the basin, the porosity is slightly lower and varies from 9.1 to $11.9 \%$ (Jarzyna and Bała, 2005; Kozłowska, 2009, 2011). In addition, a weak correlation between porosity and genesis of sandy rocks was noted by Kozłowska (2009). The deltaic (mouth bar) sandstones, represented mainly by subarkosic or sublithic arenites, occasionally even by wackes, are characterized by a higher amount of clayey matrix and lower porosity. By contrast, the fluvial quartz arenites have a slightly higher porosity.

In recent years, reservoir parameters, as well as shale volume and effective porosity, have mainly been estimated from selected geophysical well logs. According to Ingersol (1990), Large and Ingersol (1997), Bhattacharya et al. (2005) and De Ros and Goldberg (2007), the integration of detailed core sample data and wireline log interpretation is used to determine the rock properties and thereby identify the reservoir horizons. This type of data processing can be very useful and is termed as petrofacies analysis. In this paper, the term petrofacies is used in the context of the sandy rocks with specific lithological, 


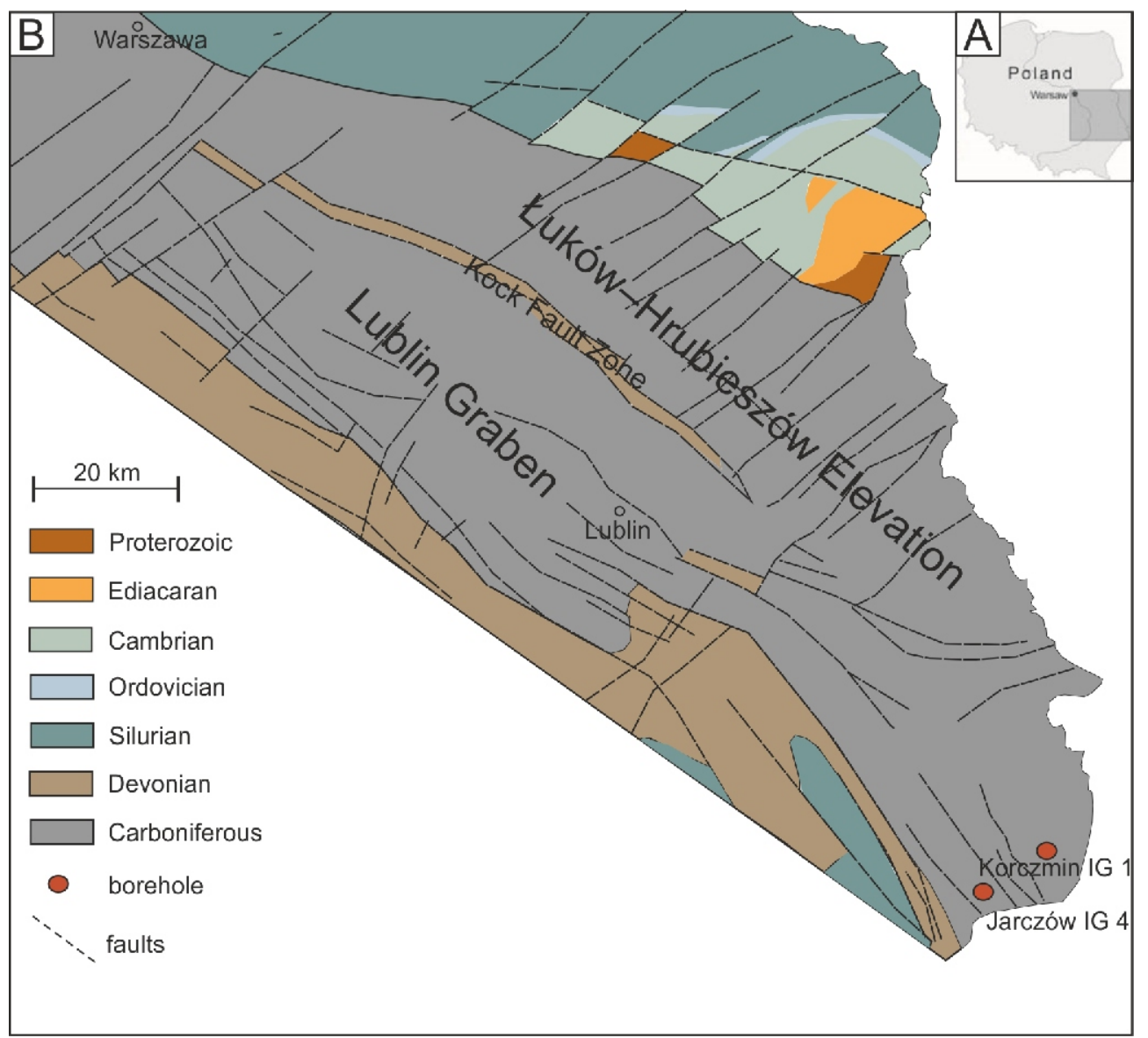

Fig. 1A - location of the Lublin Basin in Poland; B - geological sketch-map of the Lublin area, without strata younger than Carboniferous (modified after Waksmundzka, 2010) with location of the studied core-section

petrographic and geophysical properties. This study shows the influence of variable primary and diagenetic mineralogical components on the reservoir properties of the sandy rocks, as detectable on natural gamma-ray and density logs. The influence on geophysical logs is studied by example of the Dęblin Formation, cored in the Jarczów IG 4 and Korczmin IG 1 boreholes, situated in the southeastern part of the Lublin Basin (Fig. 1). The Dęblin Formation sandy rocks were selected because of their high content of muscovite/sericite grains and illite, which strongly modify the natural gamma-ray intensity. The occurrence of certain diagenetic minerals is also crucial as regards proper estimation of the average density of the grain framework, as used to calculate effective porosity. Diagenetic carbonates and pyrite, also observed in the sandy rocks, strongly increase the bulk rock density as shown on the density logs. A fuller understanding of the variablility of the mineralogical composition of these sandy rocks is essential to the proper calculation of the reservoir rock parameters and important to predicting the probable conditions of hydrocarbon generation.

\section{GEOLOGICAL SETTING}

The Dęblin Formation is formed mainly of sandstones and heterolithic strata, with some intercalations of shales, organic-rich rocks (mainly coals) and limestones of deltaic/fluvial origin (Porzycki, 1988; Porzycki and Zdanowski, 1995; Waksmundzka, 2010). It represents a part of the Middle Vise-
an-Upper Westphalian paralic-limnic series of the Carboniferous Lublin Basin located in southeastern Poland (Fig.1) (Żelichowski, 1972; Porzycki and Zdanowski, 1995; Waksmundzka, 1998, 2010). The deposition of the Carboniferous productive succession was preceded by Late Devonian/early Carboniferous erosion caused by the earliest tectonic phase of the Variscan orogeny, which rebuilt the architecture of the basin and caused tectonic inversion (Narkiewicz, 2007). The thickness of the Carboniferous rocks reaches $3500 \mathrm{~m}$, with a general increase towards the south-west (Żelichowski, 1972; Waksmundzka, 2010).

The northern and southwestern boundaries of the Lublin Basin are defined by fault zones, whereas the eastern and southeastern part of the Lublin Basin is bounded by the present-day, sub-Permian/Mesozoic extent of the Carboniferous rocks (Żelichowski, 1972; Narkiewicz, 2007; Żelaźniewicz et al., 2011). The Carboniferous rocks lie unconformably on older, Paleozoic and Ediacaran rocks, as well as on the crystalline basement (Żelaźniewicz et al., 2011). During the Variscan orogeny, the Carboniferous infill of the basin was folded into NW-SE trending folds and overlain by Permian-Mesozoic strata.

The Lublin Basin is divided by the Kock fault zone into two tectonic units: the Lublin Graben (Trough) in the west and the Łuków-Hrubieszów Elevation in the east (Fig. 1B). The Łuków-Hrubieszów Elevation is not very tectonically varied by contrast with the Lublin Graben. The variable distance to the stable East European Platform means that the western part of the basin has been tectonically re-built and slightly metamor- 


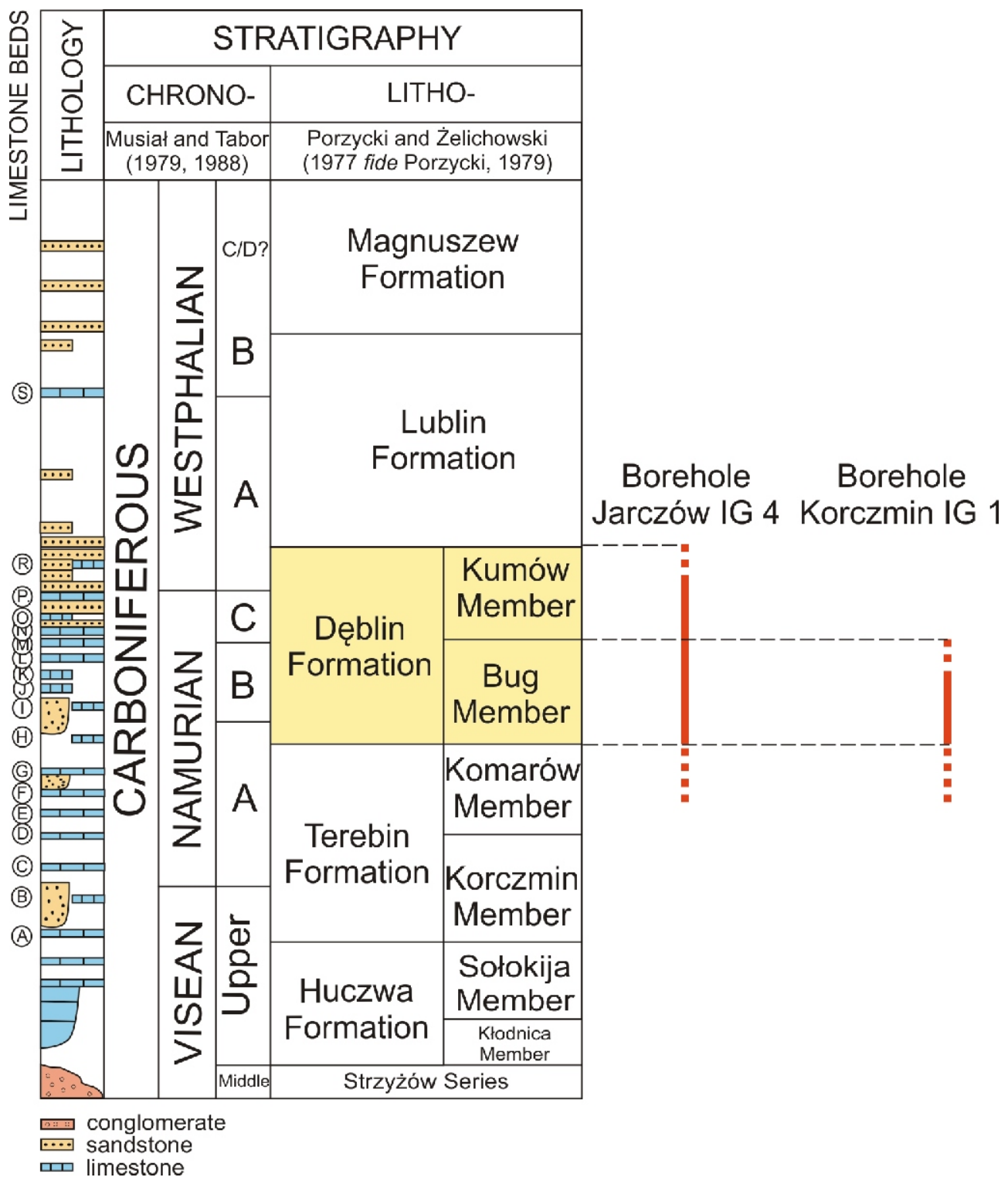

Fig. 2. The lithostratigraphy of the Carboniferous in the Lublin Basin (after Waksmundzka, 2010)

Namurian A, B, C and Westphalian A, B, C, D - regional subdivisions of European chronostratigraphic units (corresponding to the internationally used Serpukhovian, Bashkirian and Moscovian stages)

phosed (Żelichowski, 1964). The thickness of the Carboniferous rocks is also higher in the western part in comparison to the Łuków-Hrubieszów Elevation because of strong subsidence on the edge of the East European Platform (Żelichowski, 1964).

The thickness of the Dęblin Formation varies from 40 up to $560 \mathrm{~m}$, generally increasing towards the south. Because of the fluvial/deltaic origin of the Dęblin Formation, its diachronous boundaries cause some difficulties as regards precisely determining the age. Detailed biostratigraphical analyses, based mainly on assemblages of macro- and microflora in fluvial and deltaic deposits and macro- and microfauna in the intercalations of marine limestones, marls and brackish claystones, indicate a latest Namurian A to Early Westphalian A age of the Dęblin Formation (Skompski, 1986, 1996, 1998; Kmiecik, 1995 Musiał and Tabor, 1995; Soboń-Podgórska and Tomaś, 1995).

The Dęblin Formation is divided into the Bug and the Kumów members (Fig. 2; Porzycki, 1988; Porzycki and Zdanowski, 1995). The Bug Member is represented mainly by mudstones and claystones with thin intercalations of coal. Besides these clastic and organic rocks, the unit includes also intercalations of marine limestone and marl (K, L, M on Fig. 2), which form well-defined biostratigraphic and geophysical correlation horizons in the Lublin Basin. The lower boundary of the Bug Member is determined by the first occurrence of several metres-thick micaceous sandstones, called "silver sandstones", above claystones with marine and brackish assemblages of molluscs and goniatites defined as the Posidonia corrugata I horizon (according to Porzycki, 1979, 1988). The Kumów Member is represented mainly by coarse clastic rocks - sandstones, conglomerates, heteroliths and some siltstones, with thin intercalations of mudstone and coal. By contrast with the Bug Member, the sandy rocks of this unit are characterized by a relatively lower content of mica. The lower boundary of the Kumów Member is determined as the base of limestone $\mathrm{N}$, which is defined as the marine faunal horizon with specific assemblages of micro- and macrofauna typical of the Namurian B 
(Musiał and Tabor, 1995). Moreover, above the Kumów Member a rapid change in lithology is observed - the sandy facies disappear and a dominance of mudstones and claystones is noted.

The Dęblin Formation is one of the sandiest lithostratigraphic units in the Carboniferous succession of the Lublin $\mathrm{Ba}$ sin. The sandy rocks of the Dęblin Formation in the northwestern and central part of the basin were the main focus of Kozłowska's $(2003,2004,2009)$ petrographic studies. The main component of sandstones of the Dęblin Formation is quartz (60-70\%). Alkaline feldspars dominate over plagioclase, which together represent $\sim 6 \%$ of the rock. Muscovite is more frequent in wackes than in arenites and its content can rise much higher than $3 \%$. In studied sandstones, heavy minerals such as zircon, titanite, rutile and apatite were observed. Lithic grains are not very common in the northwestern and central parts of the basin and form only $\sim 2 \%$ of grains. The matrix is composed mainly of allo- and authigenic clay minerals which are difficult to distinguish. Kaolinite is dominant and it can form from 4 up to $19.3 \%$ of the matrix. Mixed-layered illite-smectite and chlorite are also common. Quartz is an important component $(1-20 \%)$ of the matrix. It represents fine grains dispersed in the matrix and authigenic cement in the sandstones (Kozłowska, 2009). The early-burial cementation processes stopped the mechanical compaction. However, the authigenic quartz, kaolinite, fibrous illite and carbonates such as siderite, Fe-dolomite, ankerite, and Fe-calcite contribute to the porosity reduction. Secondary dissolution of feldspar grains and other rock components formed a secondary porosity. Carbonate cements are very common in the Dęblin Formation sandstones and can create up to $45 \%$ of a sandstone's pore space (Kozłowska, 2009). Additionally, minerals such as pyrite, hematite, barite, and apatite are sometimes observed.

\section{MATERIALS AND METHODS}

The results presented below were derived from geological and geophysical data from the Jarczów IG 4 and Korczmin IG 1 boreholes, located in the southeastern part of the Lublin Basin (Fig. 1B). Those boreholes were chosen because of their location and the availability of borehole core and wireline data. In the lithostratigraphic interval of interest in the boreholes, respectively 62 and $56 \%$ of the Carboniferous rocks were cored.

In Korczmin IG 1 the Dęblin Formation, with the most petrographically diverse Bug Member (Fig. 2), was detected at 600-694 m b.g.l. By contrast with Korczmin IG 1, the lithostratigraphy of the Carboniferous succession has not yet been established in Jarczów IG 4. Hence, accordingly to Porzycki's (1979) lithostratigraphic criteria, the Dęblin Formation was considered as the $41 \mathrm{~m}$ thick succession of "silver" micaceous sandstones cored between 964.6 and $1005.6 \mathrm{~m}$ b.g.l.

To fully understand the genesis of the sandstones a sedimentological analysis was carried out. Lithofacies and textural observations were performed on core material from both boreholes. Into account were taken the dominant grain size, colour, sedimentary structures, the mineralogical composition of the sandy rocks (with particular emphasis on the content of micaceous grains and the occurrence of pyrite, siderite, and other carbonates), the content of clay laminae, and the occurrence of charred plant detritus. As a result, 6 samples of sandy rocks for petrographic analysis were selected (Table 1). Additionally, based on lithofacies lithofacies and the vertical succession, genetic associations of lithofacies were distinguished. This analysis was fundamental for interpretion of the genesis of the sandstones and of sedimentary environments, representative of the Lublin Basin (Eliott, 1986; Miall, 1996; Waksmundzka, 2010).

Table 1

Sandstone samples from the Korczmin IG 1 and Jarczów IG 4 core sections (Polish Ministry of the Environment agreements nos $1158 / / G / 2015$ and $1258 / I G / 2017$ )

\begin{tabular}{|c|l|c|}
\hline Sample & Lithology & Depth [mb.g.I] \\
\hline \multicolumn{3}{|c|}{ Korczmin IG 1 } \\
\hline K1 & sandstone & 640.6 \\
\hline K2 & sandstone & 651.6 \\
\hline K3 & sandstone & 679.8 \\
\hline K4 & sandstone & 687.7 \\
\hline \multicolumn{3}{|c|}{ Jarczów IG 4 } \\
\hline J1 & sandstone & 921.4 \\
\hline J2 & sandstone & 970.9 \\
\hline
\end{tabular}

Petrographic analysis of thin sections of the samples collected was made. This focused on the description of primary features of the sandy rocks such as grain size, mineral composition, the type and content of matrix, texture, and secondary features such as diagenetic mineralization, necessary to define reservoir sandstone parameters. To classify the sandstone and estimate its porosity, a planimetric counting procedure was used. A grid was chosen for every sample individually, considering the maximum grain size. 300 counts per section were made to evaluate the percentage of quartz, feldspars and lithic grains based on the Pettijohn et al. (1972) classification of sandstones. The diagenetic mineralization and grain contacts were also analysed. NIS-Elements software was used to take microphotographs of the samples. Additionally, SEM analysis was made on the 6 samples to support the results of optical petrographic analysis and to study the morphology of the sandstone components.

Next, conversion and normalization of geophysical source data was carried out (Fig. 3), to estimate the reservoir sandstone parameters (Jarzyna et al., 1999; Szewczyk, 2000; Bolesta and Gałązka, 2014). In the older boreholes (made before the 1990s) the intensity of gamma-ray was measured by Soviet-type tools and the measurements were shown on the log in counts per minute - cpm, which are not comparable to standard gamma-ray units. Moreover, the gamma-ray intensity measurements, made for the same rocks, cannot be inter-compared because of the different accuracies of the tools used. The conversion of cpm units into standard gamma-ray units (API) was made according to Bolesta and Gałązka (2014). The normalization of density source data (in $\mathrm{cpm}$ ) into $\mathrm{g} / \mathrm{cm}^{3}$ units was made only for the Dęblin Formation depth interval and was two-stage. Firstly, a standard method of data normalization, commonly used by the petroleum industry, was carried out. Then, the correctness of the average of grain-framework density was calculated and applied, allowing proper re-counting of the bulk rock density data for the sandy rocks. The correction was necessary because the grain-framework average density was higher than for normal quartz arenites and wackes as a result of the siderite and/or pyrite mineralization. A minimum bulk density $\left(2.4 \mathrm{~g} / \mathrm{cm}^{3}\right)$ was assumed for clean quartzitic sandstone with $22 \%$ of pore space filled with formation water, $60 \%$ with quartz, $15 \%$ with muscovite and $3 \%$ with dense minerals such as pyrite or siderite. A maximum of $3 \mathrm{~g} / \mathrm{cm}^{3}$ was estimated for non-porous sandstones with a high $(10 \%)$ content of high-density minerals, $40 \%$ of muscovite and $65 \%$ of quartz or feldspars. 


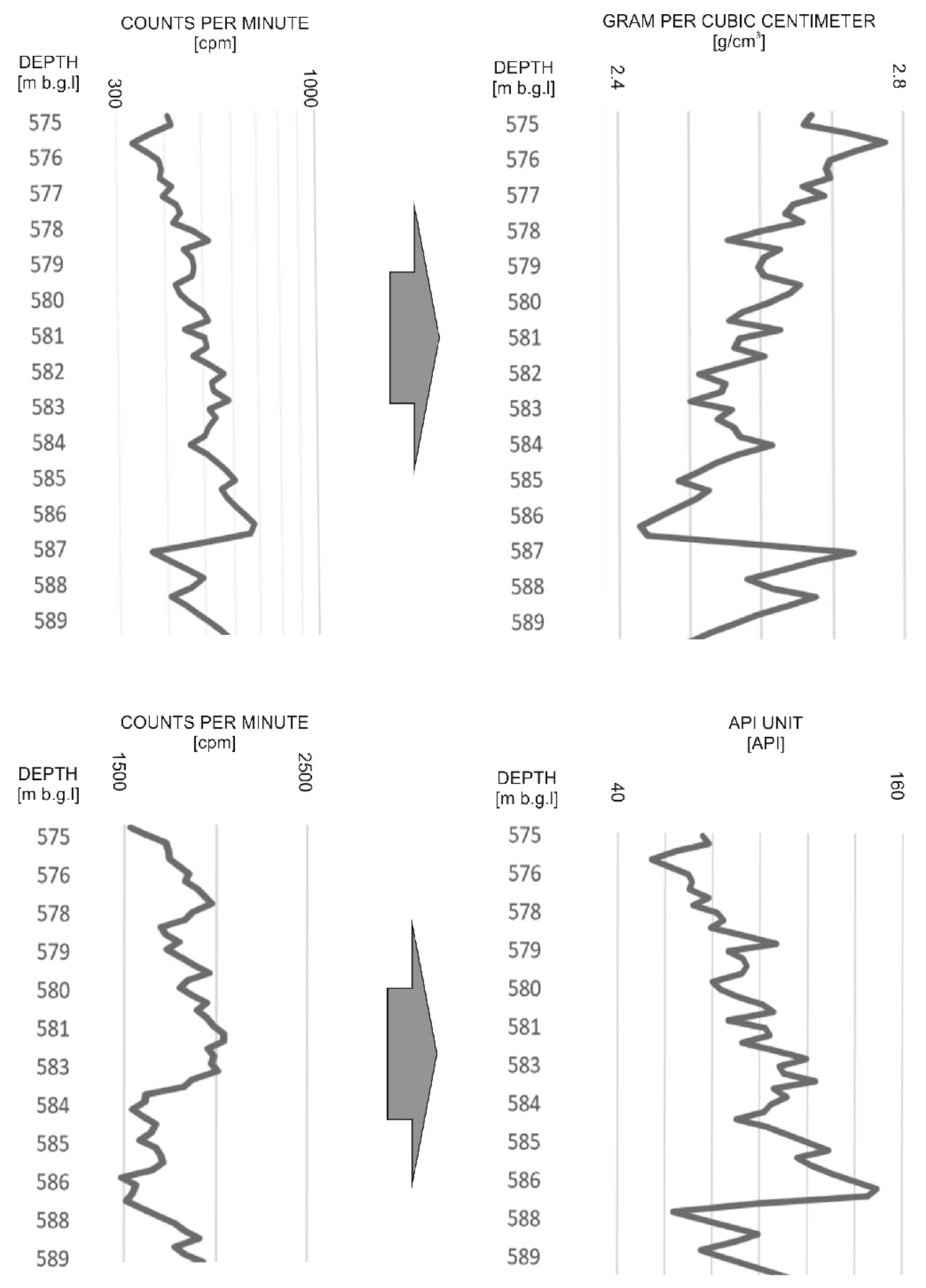

Fig. 3. Example of applied bulk density and gamma-ray log recount procedures (Korczmin IG 1 borehole depth 575-589 m b.g.I.)

Finally, the geophysical parameters were compared with the data obtained in the petrographic analysis. As a result of this comparison, sandy petrofacies were distinguished for the Dęblin Formation. Each petrofacies is characterized by the limits of natural gamma-ray and bulk density values based on physical and chemical features of the primary and diagenetic components, as interpreted by the petrographic analysis of particular sandstones. Analysis of the natural gamma-ray and density logs was also used for proper re-interpretation of the lithology of uncored intervals and for the correction of depths.

\section{SEDIMENTOLOGY}

Based on the lithofacies analysis of core samples and their succession, 5 different genetic associations were distinguished (Table 2).

Sandy rocks of the Dęblin Formation were deposited in fluvial and deltaic environments. The sandy/heterolithic associations are composed of lithofacies with vertical patterns typical of sandy braided river channel and bar deposits (Fig. 4B), crevasse splay deposits (Fig. 4A), deltaic distributary channels 
(DCH), and mouth bars (MB; Fig. 4C). The sandy rocks are lithosomes within fluvial and delta plain fine-grained deposits. The fluvial/deltaic origin of the Carboniferous rocks from the Lublin Basin was interpreted and widely discussed by Waksmundzka (2010).

High flow velocity and intense erosion in braided river channels $(\mathrm{CH})$ and distributary channels of a delta plain $(\mathrm{DCH})$ are reasons why these sandstones are better sorted and therefore characterized by lower clay and muscovite contents; thus, this type of rock usually has higher primary porosity and shows better reservoir properties (Liu et al., 2015; Fan et al., 2019). However, this structure is also favourable for the percolation of diagenetic fluids which can be a further reason for porosity reduction (Yang et al., 2014). Sideritized clay clasts and plant fragments are common because of the intense erosion of flood/delta plain deposits. Higher contents of muscovite grains and shale laminae are mostly present in the mouth bar (MB) and crevasse splay (CS) deposits (Fig. 4A, C). Siderite is present as concretions or as part of the matrix. These sandstones are also interbedded with heterolithic strata. These kinds of rocks develop during the main flood stages after breaching of the levees. Originally high-velocity flow rapidly slows and causes rapid deposition of poorly sorted, micaceous sediment. A similar situation happens while the mouth bars are forming, where the sedimentation is the result of flow deceleration and of rapid change in water density (Eliott, 1986).

\section{PETROGRAPHY OF THE SANDY ROCKS}

The sandstones of the Deblin Formation from the Jarczów IG 4 and Korczmin IG 1 core-sections represent mainly lithic and sublithic arenites and wackes (Fig. 5). Quartz is the main component of the sandstones analysed (60-88\%) but lithic grain content is also significant (11-55\%). The majority of observed rock fragments are of siliceous rocks like cherts, (Fig. 6C) or polycrystalline quartz (Fig. 6A, C, E, F), is perhaps derived from earlier sandstones. Quarzite and quarzitic sandstone grains are also common (Fig. 6A, C, E, F). Feldspars occur sporadically $(1-2 \%)$ and they are mainly represented by alkaline feldspars, rarely plagioclases (Fig. 7C). In many samples, mica grains - biotite and muscovite - are usually chloritized or sericitized (Figs. 6E, F and 7A, C).

In the samples analysed from the Korczmin IG 1 and Jarczów IG 4 boreholes, different types of diagenetic mineralization were observed. Most commonly for the Dęblin Formation, carbonate, siderite, and quartz cements developed in the pore space (Fig. 6A, C, E, F) and they form up to $15 \%$ of the rock. In thin section, authigenic quartz overgrowths were often observed on detrital grains (Fig. 6C). The quartz mineralization together with the sideritization, which developed through the recrystallization of clay minerals (Fig. 6B), probably reflects early burial. Probably, the kaolinization of feldspars and chloritization of mica took place simultaneously. The presence of early diagenetic cements in sandstones of the Dęblin Formation is often the reason for the preservation of high primary porosity through preventing compaction (Kozłowska, 2009). Moreover, the kaolinitization of feldspars can cause the devel- opment of secondary porosity. The illite visible in samples $\mathrm{J} 1$ and $\mathrm{J} 2$ of the sandstones (Fig. 8D) is probably the result of intensified diagenetic processes in the more deeply buried Lublin Graben. In all the arenites analysed, the grain contacts are elongated or concave-convex, probably developing through the effect of high lithostatic pressure during diagenesis in the Lublin Basin, as noted by Kozłowska (2009).

\section{PETROFACIES OF THE SANDY ROCKS}

Based on the petrographic analysis and mineral composition, 2 different sandy petrofacies were distinguished (Fig. 9):

- petrofacies A - non-porous (cemented) and porous sandstones, shaly sandstones and heterolithic deposits with diagenetic mineralization of carbonates and pyrite;

- petrofacies B - non-porous and porous sandstones and/or heterolithic deposits with a high content of muscovite ("silver sandstones").

Petrofacies $A$ has been divided into 2 sub-petrofacies on the basis of the differences in clay mineral content (especially illite), detectable on a gamma-ray log (Fig. 9). Petrofacies B has been distinguished on the basis of higher gamma-ray values (above $60 \mathrm{API}$ ) by comparison with petrofacies A. These relatively high values, which are not typical for sandstones, suggest a higher content of radioactive elements - probably micas and/or illite. On the basis of differences in bulk rock density in petrofacies B, sub-petrofacies B1 and B2 were distinguished. The differences in the measured bulk rock density are probably caused by a higher content of high-density minerals such as carbonates and pyrite, characterized by density exceeding $2.71 \mathrm{~g} / \mathrm{cm}^{3}$.

For every sandy lithotype, representative intensities of natural gamma-ray and bulk rock density range were determined (Table 3).

A diverse mineral composition in the Dęblin Formation is the main reason for the variable geophysical characteristics of the sandy rocks analysed. These rocks are mainly represented by lithic and sublithic arenites and wackes (Table 3), but differences in the contents of the primary and diagenetic radioactive minerals can change the predicted geophysical measurements. The natural gamma-ray intensity is usually higher than $20 \mathrm{API}$ and it very commonly reaches $110 \mathrm{API}$. Also, bulk rock density changes are observed in a wide range from 2.5 to $2.95 \mathrm{~g} / \mathrm{cm}^{3}$, which indicates changes in the effective porosity and in the occurrence of admixtures of high- and low-density rock elements (Fig. 10).

Petrofacies analysis was fundamental to recognition of the lithology, primary mineral composition and rock properties in un-cored intervals in both boreholes. There is also a visible correlation between the probable sedimentary origin and the sandstone type. Petrofacies A is mostly present in river channel and distributary channel deposits because of its better sorting and lower clay content. Petrofacies B however, is more characteristic of crevasse splay and mouth bar deposits. The lithological and geophysical data compiled together with results of the sedimentological and petrofacies analysis are shown in Figures 11 and 12 . 
Lithofacies characteristics of the genetic associations and their inferred genesis

\begin{tabular}{|c|c|c|c|c|}
\hline $\begin{array}{c}\text { Genetic association } \\
\text { of lithofacies }\end{array}$ & $\begin{array}{c}\text { Vertical succession } \\
\text { of lithofacies }\end{array}$ & $\begin{array}{l}\text { Contact } \\
\text { associations }\end{array}$ & Diagnostic features & $\begin{array}{c}\text { Genesis (on the basis of } \\
\text { Cant and Walker, 1978; } \\
\text { Elliott, 1986; Miall, 1996; } \\
\text { Zieliński, 1998) }\end{array}$ \\
\hline $\begin{array}{l}\text { Channel fill and } \\
\text { sandy bar deposits } \\
(\mathrm{CH}) \text { (Fig. 4B) }\end{array}$ & $\begin{array}{c}\mathrm{Sm} /(\mathrm{SGm}) » \mathrm{Sp} / \mathrm{SI} \\
\text { "(Ssh) } " \mathrm{Sh} » \\
\mathrm{Sr} / \mathrm{Hr} » \mathrm{Hh}\end{array}$ & CS, FP & $\begin{array}{l}\text { - successions of sandy lithofacies } \\
\text { from } 5 \text { to } 40 \text { metres of thick; } \\
\text { - cycles are characterized by fin- } \\
\text { ing upward trends and domination } \\
\text { of cross-bedded lithosomes; } \\
\text { - the occurrence of sideritic and } \\
\text { clay clasts and detritus of flora } \\
\text { fragments accumulations } \\
\text { (lithofacies SGm); } \\
\text { - erosional boundaries of sandy } \\
\text { lithosomes }\end{array}$ & $\begin{array}{c}\text { By aggradation of sandy } \\
\text { bars in the channel zone } \\
\text { of high-energy sandy } \\
\text { braided rivers }\end{array}$ \\
\hline $\begin{array}{l}\text { Crevasse splay de- } \\
\text { posits (CS) (Fig.4A) }\end{array}$ & $\begin{array}{c}\mathrm{Sm} » \mathrm{Tm} \text { » } \mathrm{Sr} /(\mathrm{Hr}) \\
\mathrm{Sm} \text { »Sh (Hh)» } \\
\mathrm{SI} /(\mathrm{Sp}) » \mathrm{Sr}(\mathrm{Hr})\end{array}$ & $\mathrm{CH}, \mathrm{FP}$ & $\begin{array}{c}\text { - successions of heterolithic and } \\
\text { sandy lithofacies with ripple } \\
\text { cross-lamination, often with a bot- } \\
\text { tom layer of massive sandstones } \\
\text { and siltstones; } \\
\text { - thickness averages between } 1 \\
\text { and } 4 \text { metres; } \\
\text { - cycles are characterized by fin- } \\
\text { ing upward trends and domination } \\
\text { of ripple cross-laminated } \\
\text { lithosomes }\end{array}$ & $\begin{array}{c}\text { During the main flood } \\
\text { stages of floods after } \\
\text { breaching of the levees, } \\
\text { when flow is initiated on } \\
\text { floodplains. Then the flow } \\
\text { velocity rapidly slows and } \\
\text { the sandy ripples are } \\
\text { formed }\end{array}$ \\
\hline $\begin{array}{l}\text { Floodplain depos- } \\
\text { its, peat, and } \\
\text { marshes (FP) }\end{array}$ & $\begin{array}{c}\mathrm{Sm} » \mathrm{Tm} / \mathrm{Th} » \mathrm{Fm} \\
\mathrm{Fh}(\mathbf{p}) » \mathrm{C}\end{array}$ & $\mathrm{CS}, \mathrm{CH}, \mathrm{DCH}$ & $\begin{array}{c}\text { - successions of fine-grained and } \\
\text { horizontally laminated deposits } \\
\text { are dominant; } \\
\text { - thickness averages between } 0.5 \\
\text { and } 14 \text { metres; } \\
\text { - a high proportion of coal layers } \\
\text { and shales with coal fragments } \\
\text { representing plant debris; } \\
\text { - occurrences of organic } \\
\text { palaeosols }\end{array}$ & $\begin{array}{c}\text { Aggradation of } \\
\text { muddy-sandy laminae as } \\
\text { the effect of sheet flow on } \\
\text { the floodplain during the } \\
\text { main flood stages. Accu- } \\
\text { mulation of plant frag- } \\
\text { ments in peats and } \\
\text { marshes of the } \\
\text { interdistributary area of the } \\
\text { delta plain. Frequent } \\
\text { weathering processes and } \\
\text { soil profile formation }\end{array}$ \\
\hline $\begin{array}{l}\text { Distributary channel } \\
\text { fills (DCH) (Fig. } 4 C)\end{array}$ & $\underset{\mathrm{Sm} /(\mathrm{Sp})}{\mathrm{Sr}}$ & $\mathrm{MB}, \mathrm{FP}, \mathrm{CS}$ & $\begin{array}{l}\text { Sandy successions between } 2 \\
\text { and } 5 \text { m thick representing the } \\
\text { topmost parts of mouth bar suc- } \\
\text { cessions; } \\
\text { - cycles are characterized by fin- } \\
\text { ing upwards trends; } \\
\text { - ripple cross-laminated sand- } \\
\text { stone lithofacies are dominant; } \\
\text { - plant fragments are commonly } \\
\text { dispersed in the sandy lithosomes }\end{array}$ & $\begin{array}{l}\text { The sandy fill of } \\
\text { interdistributary channels } \\
\text { formed during the main } \\
\text { flood phases }\end{array}$ \\
\hline $\begin{array}{l}\text { Mouth bar deposits } \\
\text { (MB) (Fig. 4C) }\end{array}$ & 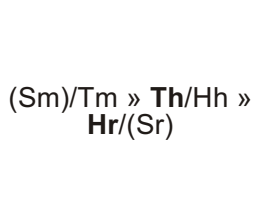 & $\mathrm{DCH}, \mathrm{FP}$ & $\begin{array}{c}\text { - heterolithic rippled lithofacies } \\
\text { are dominant; } \\
\text { - the thickness is between } 6 \text { and } \\
17 \text { meters; } \\
\text { - cycles are characterized by } \\
\text { coarsening upwards trends; } \\
\text { - high muscovite content }\end{array}$ & $\begin{array}{l}\text { Formation of mouth bars } \\
\text { as the effect of slowing of } \\
\text { flow and rapid changes in } \\
\text { water density }\end{array}$ \\
\hline
\end{tabular}

Lithofacies code: Sm/SGm - sandstones/gravelly sandstones of massive structure, Sp - sandstones with tabular cross-bedding, SI - sandstones with low-angle cross-bedding, Sh/Ssh - sandstones with horizontal/sub-horizontal bedding, Sr - sandstones with ripples, $\mathrm{Tm}$ - massive siltstones, $\mathrm{Th}$ - siltstones with horizontal bedding, $\mathrm{Hr}$ - heterolithic strata with ripples, Hh heterolithic strata with horizontal bedding, Fh - claystones and mudstones with horizontal lamination, Fm - claystones and mudstones of massive structure, $\mathrm{Fh}(\mathrm{p})$ - claystones and mudstones with horizontal lamination and accumulations of coaly fragments, $\mathrm{C}$ - coal; bold fonts are used for the main lithofacies in the association 
A

DEPTH

[m b.g.I]

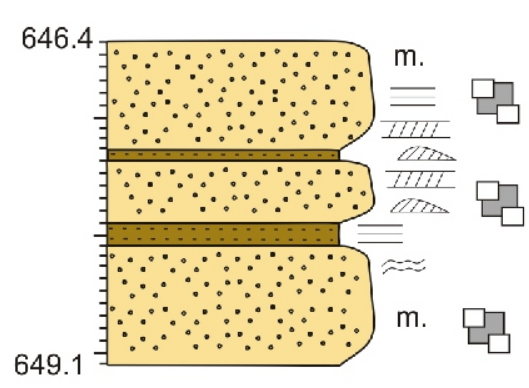

C

DEPTH

[m b.g.l]

920.4

924

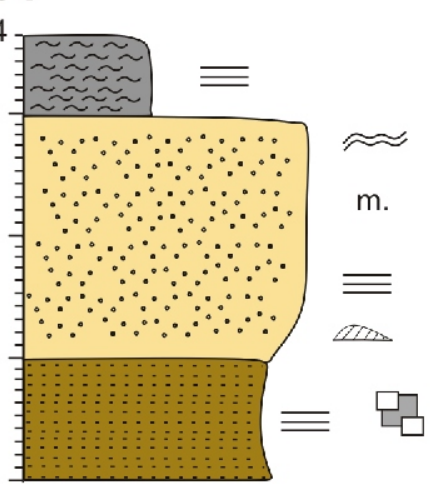

$4 \mathrm{CH}$

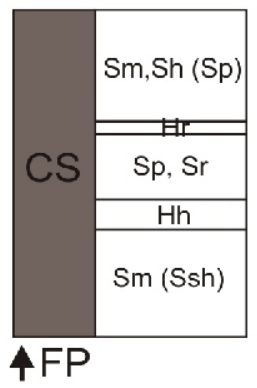

B

DEPTH

[m b.g.I]

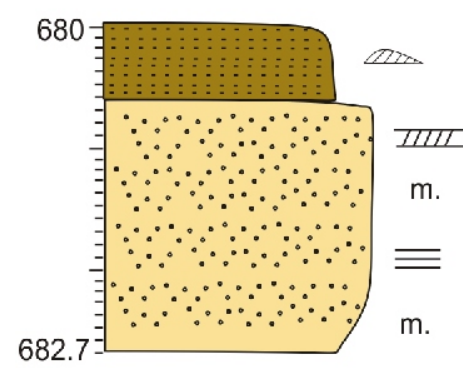

$4 F P$

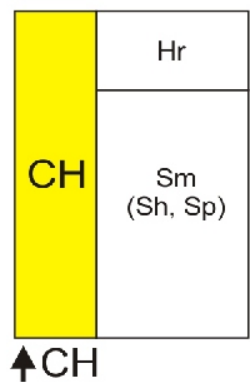

\section{$\because \because \because \because \because$ sandstone}

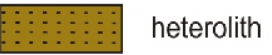

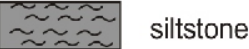

ㅁ high muscovite content

m. massive structure

$\equiv$ horizontal lamination

$\approx$ subhorizontal lamination

TTo ripple cross-stratification

IIII) planar cross-stratification

Fig. 4. Sandy lithofacies associations deposited in fluvial and deltaic environments

Korczmin IG 1 (A, B) and Jarczów IG 4 (C) boreholes; other explanations in Table 2

arenites

$<15 \%$ matrix

Q

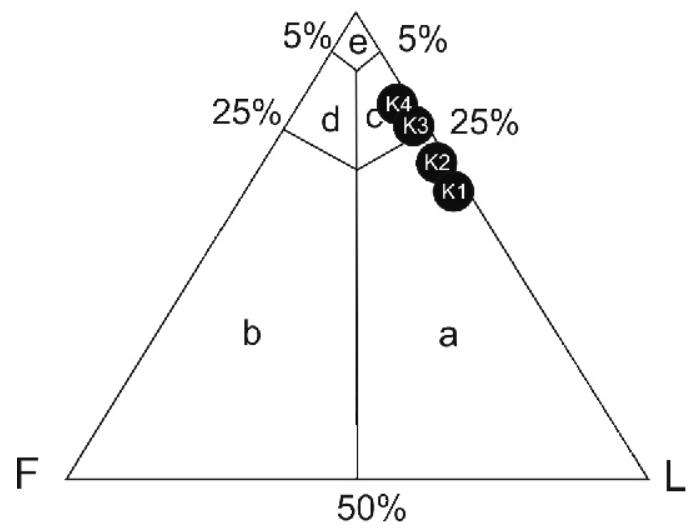

wackes

$15 \%-50 \%$ matrix

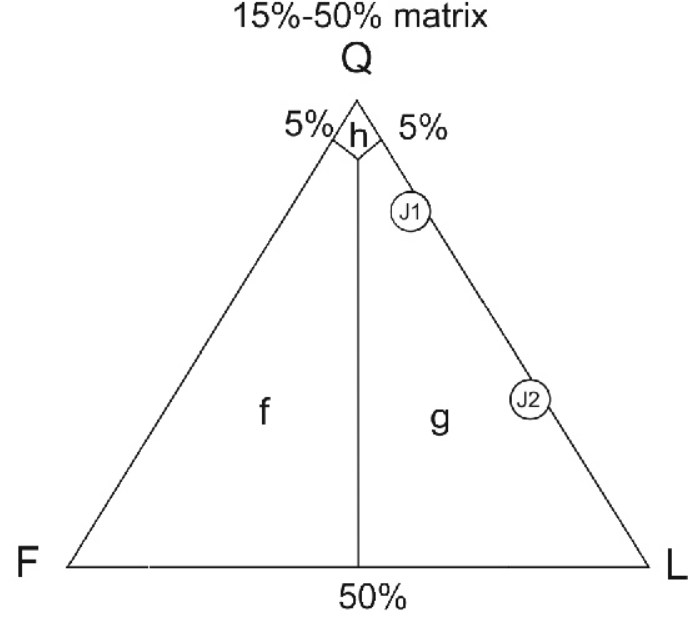

* sample from Korczmin IG 1 borehole

(1) sample from Jarczów IG 4 borehole

Fig. 5. Korczmin IG 1 (K1-K4) and Jarczów IG 4 (J1, J2) samples plotted in the Pettijohn et al. (1972) classification triangles

$\mathrm{a}$ - lithic arenite, $\mathrm{b}$ - arkosic arenite, c - sublithic arenite, $\mathrm{d}$ - subarkosic arenite, e - quartz arenite, $\mathrm{f}$ - arkosic wacke, $\mathrm{g}$ - lithic wacke, $\mathrm{h}$ - quartz wacke; $\mathrm{Q}$ - quartz, $\mathrm{F}$ - feldspars, $\mathrm{L}$ - lithic grains 

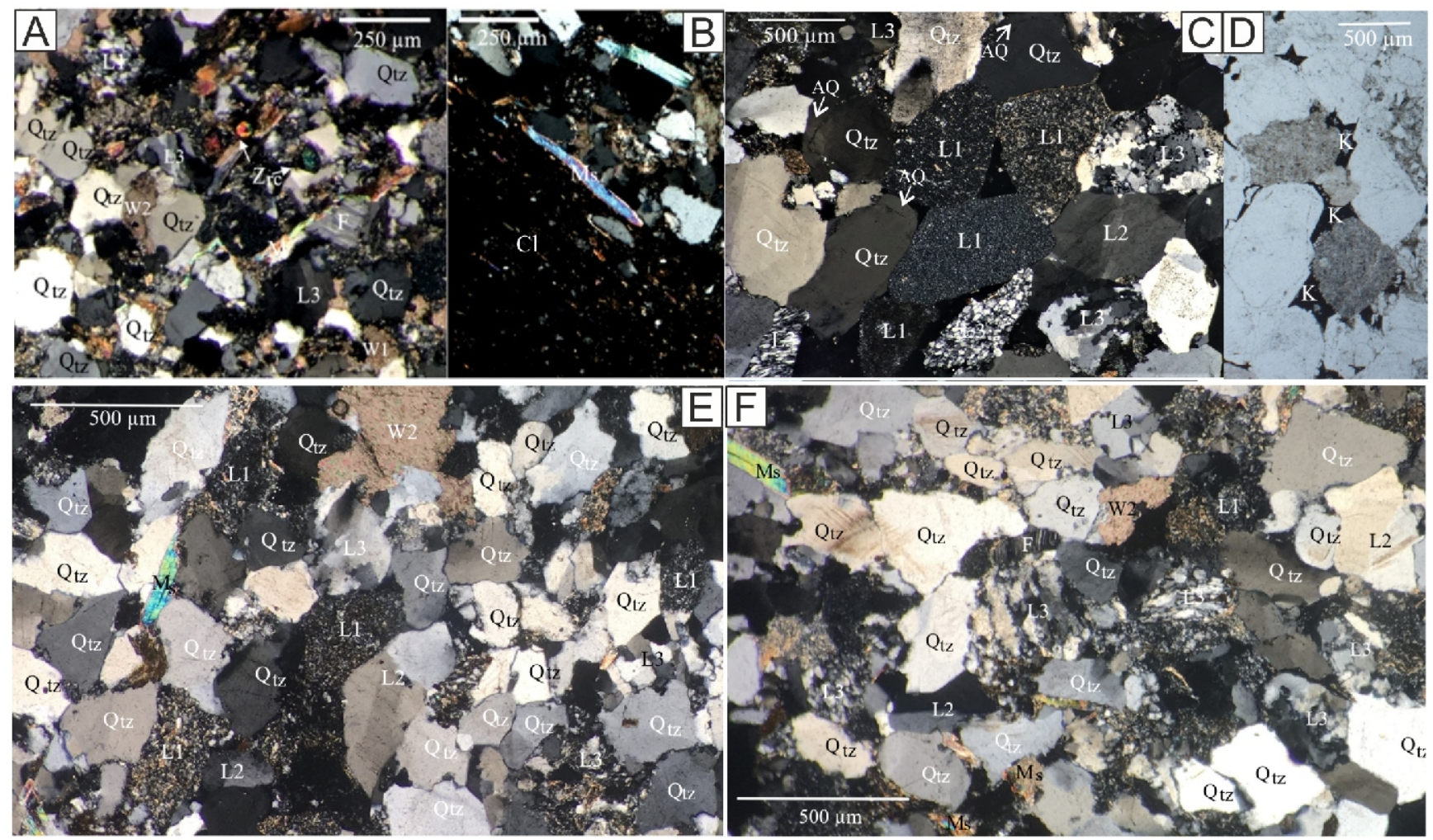

Fig. 6. Microphotographs of sandstones from the Korczmin IG 1 borehole

A, B - sample K1, crossed polars, depth: $640.6 \mathrm{~m}$ b.g.l.; C - sample K2, crossed polars; D - sample K2, plane parallel light, depth: 651.6 m b.g.l.; E - sample K3, crossed polars, depth: 679.8 m b.g.l.; F - sample K4, crossed polars, depth: 687.7 m b.g.l.; Qtz - quartz, F feldspar, Ms - muscovite; Zrc - zircon; L1 - grain of siliceous rock (chert); L2 - polycrystalline quartz; L3 - grain of metamorphic rock; AQ authigenic quartz; W1, W2 - diagenetic siderite/dolomite; $\mathrm{Cl}$ - recrystallized clay clast; $\mathrm{K}$ - authigenic iron sulphide; III - illite; OM - organic matter

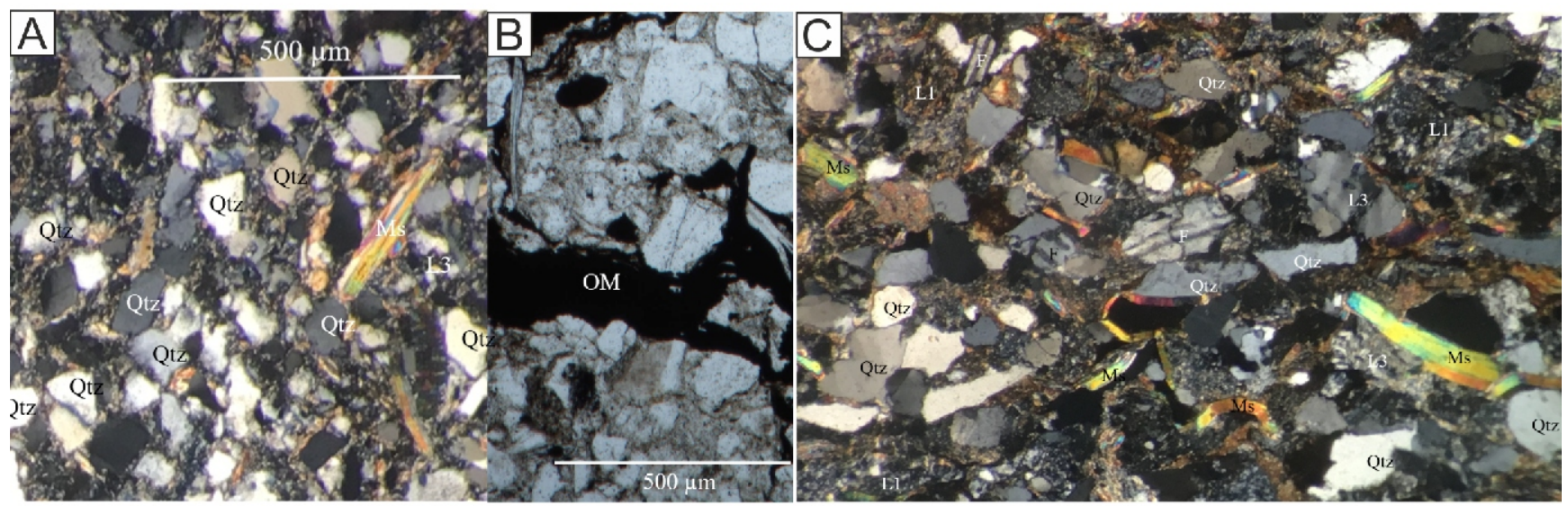

Fig. 7. Microphotographs of sandstone samples from the Jarczów IG 4 borehole

A - sample J1, crossed polars, depth: 921.4 m b.g.l.; B - sample J1, plane parallel light, depth: 921.4 m b.g.l.; C - sample J2, crossed polars, depth: $970.1 \mathrm{~m}$ b.g.l.; explanations as on Figure 6 


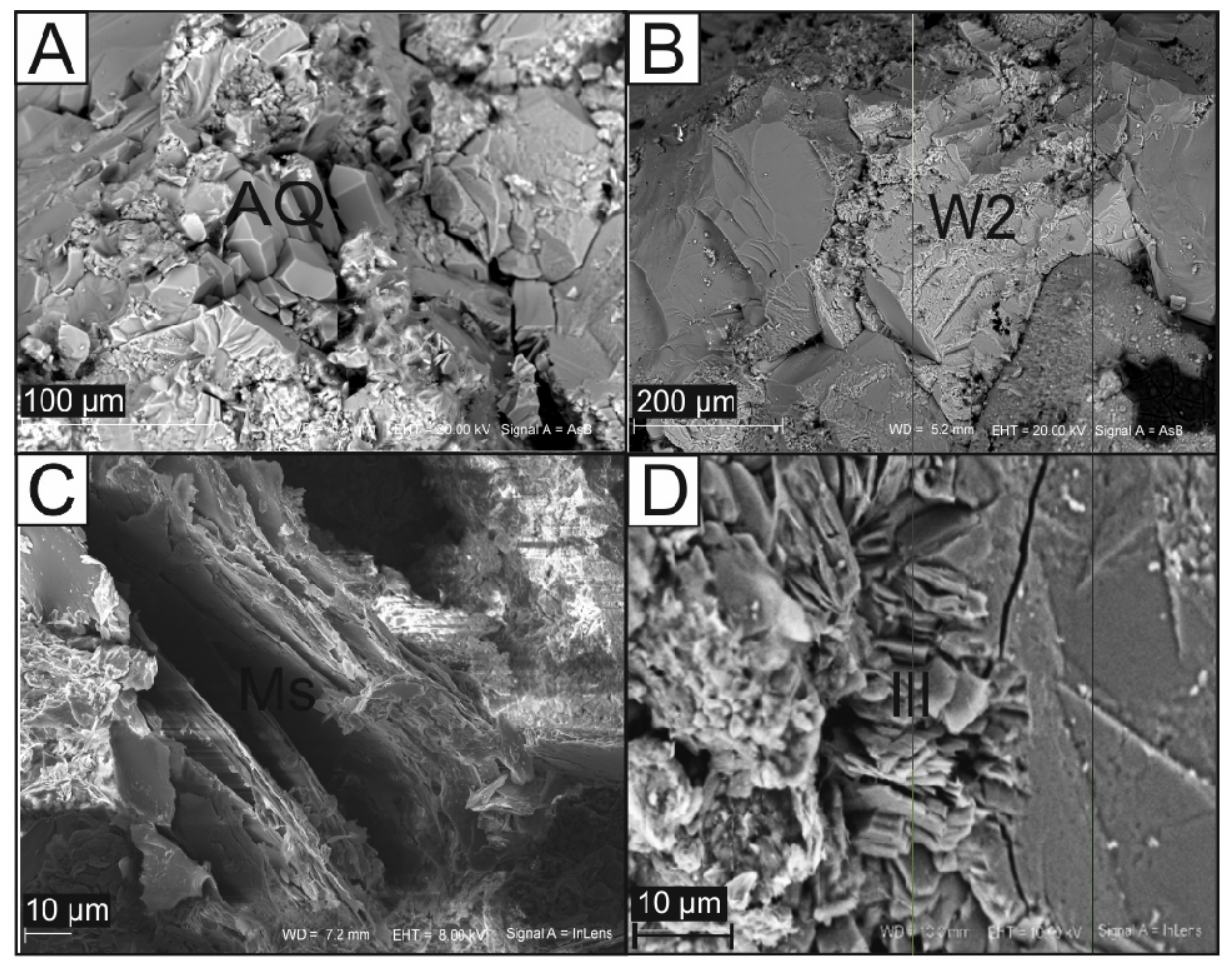

Fig. 8. SEM microphotographs from the Jarczów IG 4 and Korczmin IG 1 boreholes

A - authigenic quartz cementation in sample K2; B - carbonate cementation in sample K3; C muscovite grain in sample J2; $\mathbf{D}$ - diagenetic illite in sample J2; explanations as on Figure 6

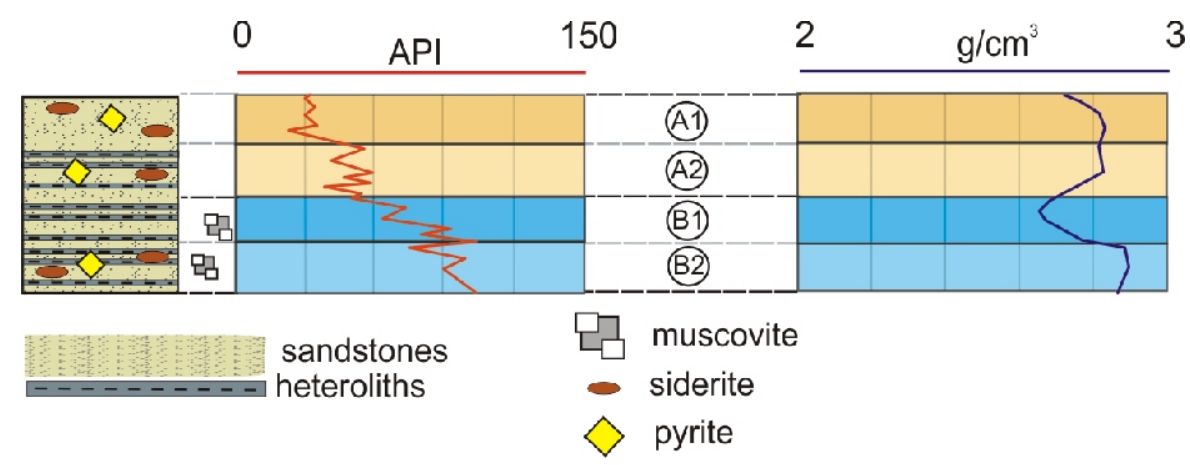

Fig. 9. The model record of geophysical parameters typical for sandy petrofacies $A$ and $B$ in the Dęblin Formation 
Representative ranges of gamma-ray intensity and bulk rock density for the sandy petrofacies

\begin{tabular}{|c|c|c|c|c|c|c|}
\hline \multirow{2}{*}{ Petrofacies } & \multirow{2}{*}{$\begin{array}{l}\text { Petrography of } \\
\text { sandy rocks }\end{array}$} & \multicolumn{2}{|c|}{ Influential components } & \multirow{2}{*}{$\begin{array}{c}\text { Gamma-ray } \\
\text { intensity }[A P I]\end{array}$} & \multirow{2}{*}{$\begin{array}{l}\text { Bulk rock } \\
\text { density val- } \\
\text { ues }\left[\mathrm{g} / \mathrm{cm}^{3}\right]\end{array}$} & \multirow{2}{*}{ Core sample } \\
\hline & & radioactive & high/low density & & & \\
\hline $\mathrm{A} 1$ & $\begin{array}{l}\text { lithic arenites, } \\
\text { lithic wackes }\end{array}$ & - & $\begin{array}{c}\text { carbonate and/or pyrite miner- } \\
\text { alization (*carbonaceous plant } \\
\text { fragments) }\end{array}$ & $20-40$ & $\begin{array}{c}\left(2.5^{\star}\right) \\
2.65-2.95\end{array}$ & $\mathrm{~J} 1, \mathrm{~K} 1$ \\
\hline A2 & lithic arenites & $\begin{array}{c}\text { clay minerals, } \\
\text { zircon }\end{array}$ & $\begin{array}{l}\text { clay minerals, carbonate } \\
\text { and/or pyrite mineralization }\end{array}$ & $40-60$ & $2.65-2.95$ & K2 \\
\hline B1 & sublithic arenites & $\begin{array}{l}\text { clay minerals, } \\
\text { muscovite }\end{array}$ & $\begin{array}{c}\text { clay minerals, muscovite } \\
\text { and/or carbonate mineraliza- } \\
\text { tion, ( }{ }^{*} \text { carbonaceous plant } \\
\text { fragments) }\end{array}$ & $60-110$ & $\begin{array}{l}\left(2.5^{\star}\right) \\
2.65-2.85\end{array}$ & $\mathrm{~K} 3, \mathrm{~K} 4$ \\
\hline B2 & lithic wackes & $\begin{array}{l}\text { clay minerals, } \\
\text { muscovite }\end{array}$ & $\begin{array}{c}\text { clay minerals, muscovite, car- } \\
\text { bonate and/or pyrite mineral- } \\
\text { ization }\end{array}$ & $60-110$ & $2.85-2.95$ & $\mathrm{~J} 2$ \\
\hline
\end{tabular}
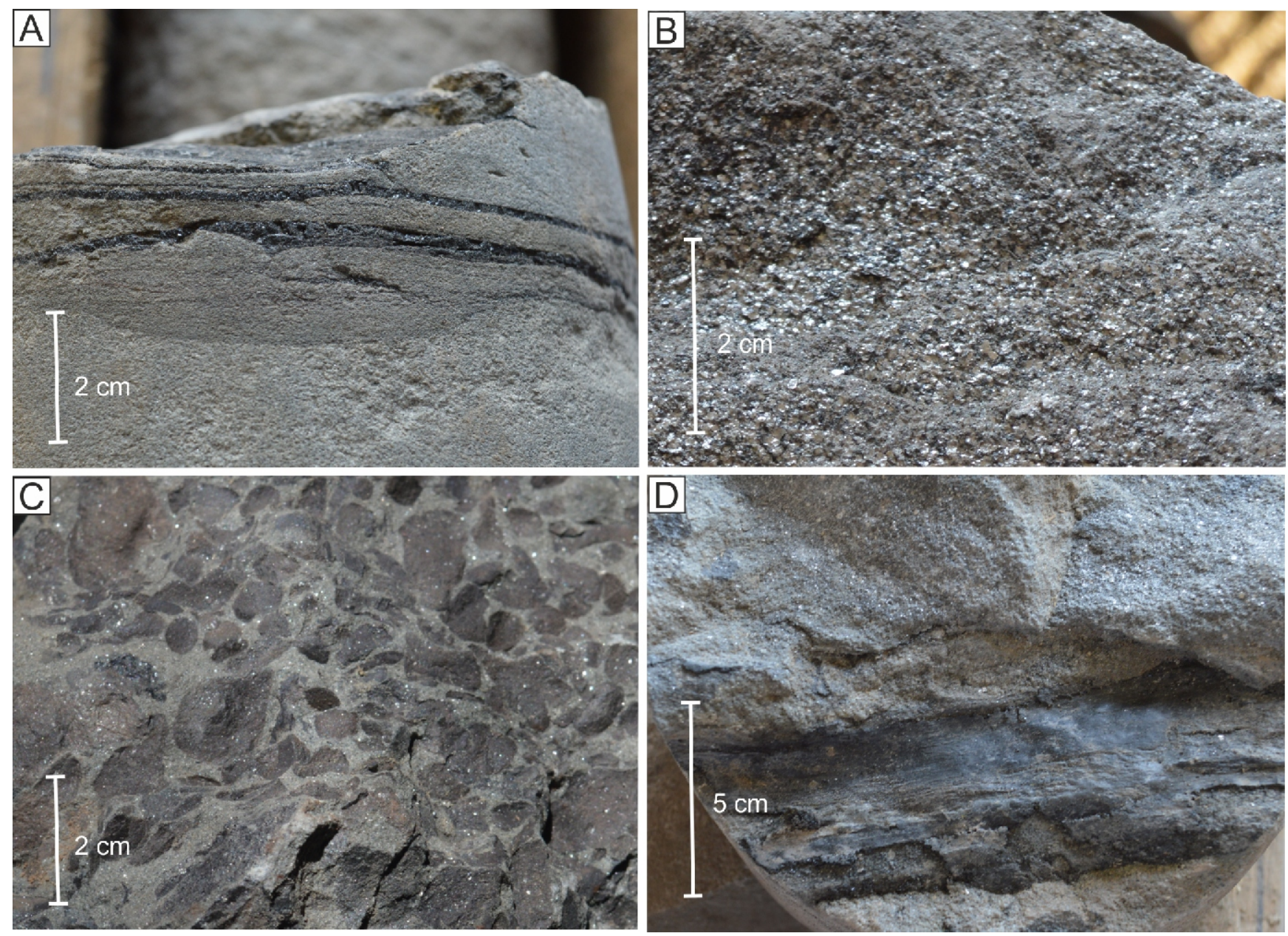

Fig. 10. Components causing changes in the bulk rock density of sandstones

A - fragments of carbonaceous plant, Korczmin IG 1, depth: $685.6 \mathrm{~m}$ b.g.l.; B - muscovite accumulation on a lamina surface Korczmin IG 1, depth: 670 m b.g.l.; C - sideritized clasts Korczmin IG 1, depth: 642 m b.g.l.; D - fragments of carbonaceous plants, Korczmin IG 1, depth: $660.5 \mathrm{~m}$ b.g.I. 


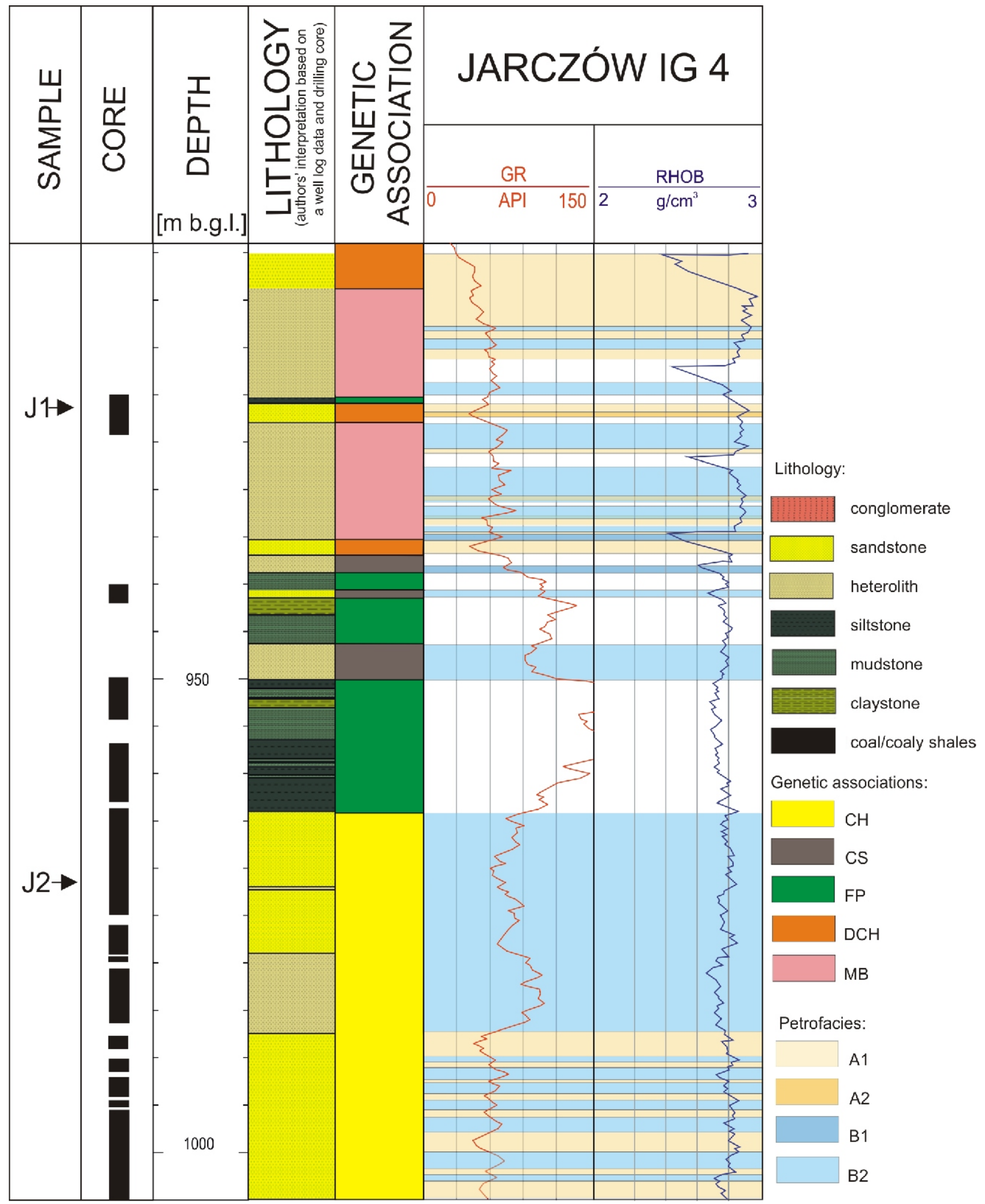

Fig. 11. Lithology combined with geophysical data and petrofacies interpretation of the Dęblin Formation in Jarczów IG 4 Explanations on Table 2 


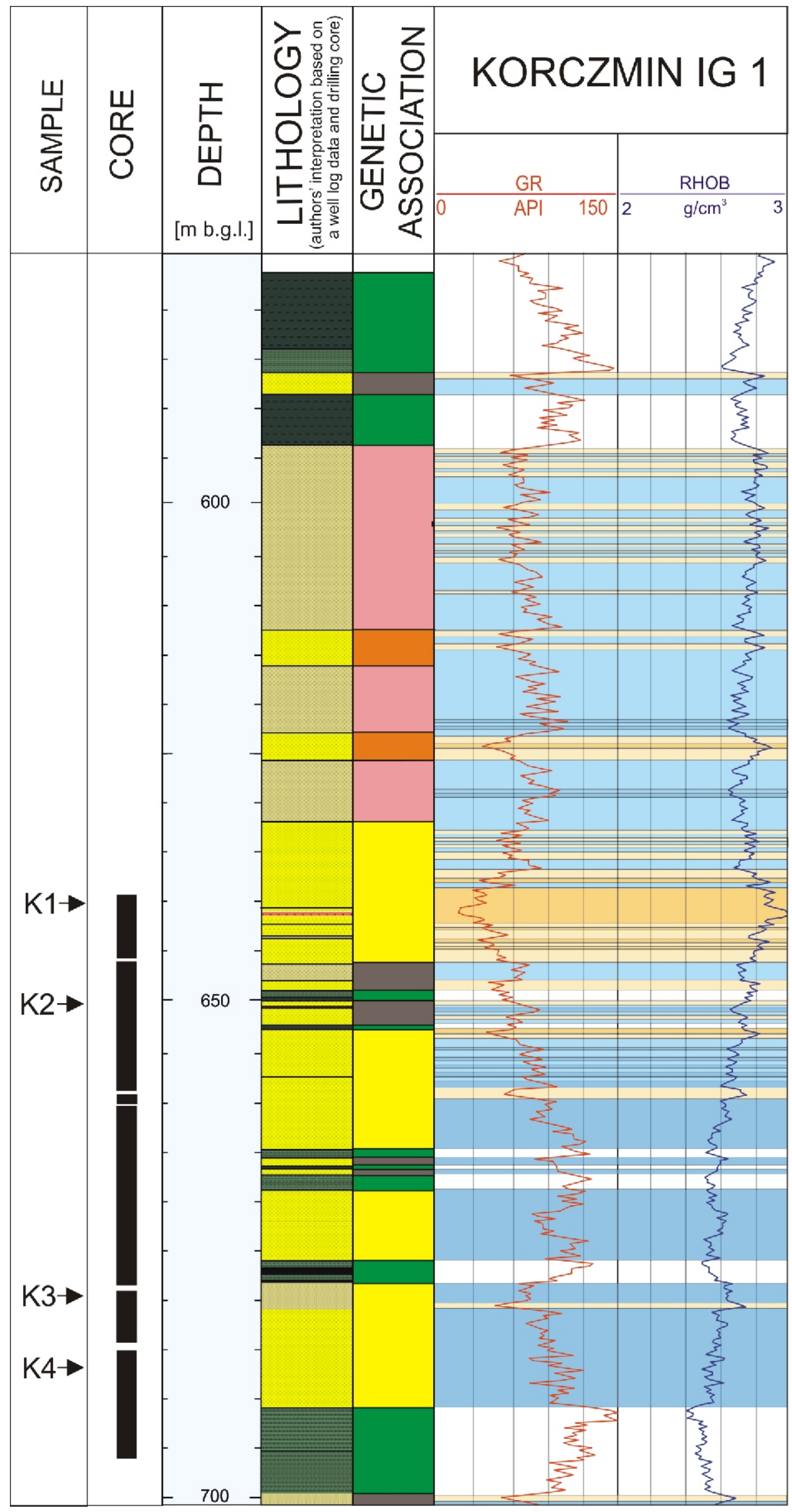

Fig. 12. Lithology combined with geophysical data and petrofacies interpretation of the Dęblin Formation in Korczmin IG 1 Explanations as in Figure 11 


\section{INFLUENCE OF PRIMARY AND DIAGENETIC MINERALS ON GAMMA-RAY AND DENSITY LOGS}

\section{INFLUENCE OF THE RADIOACTIVE ELEMENTS} ON GAMMA-RAY MEASUREMENTS

Illite, glauconite, micas (muscovite and biotite), potassium feldspar grains, clay lithoclasts and heavy minerals (e.g., zircon) are the main minerals rich in radioactive isotopes of potassium, thorium and uranium which could increase the natural gamma-ray intensity in sandy rocks (Serra, 1984; Rider, 2002). In the Carboniferous sandy rocks analysed the radioactive elements are represented mainly by diagenetic illite, often dispersed in the pore space or in the matrix in arenites and wackes. Also, primary muscovite/sericite, potassium feldspars, and zircon grains were observed in the thin sections (Figs. 6A-C, E, F and 7A, C; Table 3).

The lowest intensity of the natural gamma radiation was observed for non-porous, cemented quartz arenites of petrofacies A1 (Figs. 11 and 12). A small admixture of some radioactive elements such as mica, potassium feldspar and accessory zircon grains can cause higher measurements, up to $\sim 40$ API. Measurements of between 40 and $60 \mathrm{API}$ were observed in petrofacies A2 in the Jarczów IG 4 and Korczmin IG 1 core-sections, represented by shaly sandstones and heterolithic strata. These are probably caused by higher contents of diagenetic illite dispersed in the pore space of sandy laminae and forming the thin clay laminae in the heterolithic deposits, as can be observed in samples $\mathrm{K} 1, \mathrm{~K} 2$, and J1. A minor influence may also be accessory zircon grains noted in the thin sections (Fig. 6A). Petrofacies B - micaceous sandstones and heterolithic deposits - is mainly composed of quartz and muscovite grains, visible even by macroscopic observation (Fig. 10B; samples K3, K4, J2). The high admixture of mica grains, together with other radioactive components, are probably the main reasons for the extraordinary natural radioactivity (between 60 and $110 \mathrm{API}$ ) of these sandstones.

\section{INFLUENCE OF HIGH- AND LOW-DENSITY ELEMENTS ON THE BULK ROCK DENSITY MEASUREMENTS}

The pore volume, the density of fluids in the pore space and the grain framework density are the main factors which determine the measured bulk density of rocks (Serra, 1984; Rider, 2002). The occurrence of diagenetic high-density minerals is responsible for the increase in bulk rock density of the Carboniferous sandstones. The bulk rock density of between 2.65 and $2.95 \mathrm{~g} / \mathrm{cm}^{3}$ of petrofacies A1 and A2 is representative of non-porous/cemented lithic and sublithic arenites/wackes. Values from 2.7 until $2.95 \mathrm{~g} / \mathrm{cm}^{3}$, characteristic of petrofacies A2 and B2, are implied by the occurrence of high-density minerals. These are represented mainly by diagenetic carbonates - calcite (Fig. 8B), dolomite and siderite (visible also in by macroscopic observation - Fig. 10C). The density of the carbonates varied between $2.71 \mathrm{~g} / \mathrm{cm}^{3}$ - typical of calcite - and $3.0-3.8 \mathrm{~g} / \mathrm{cm}^{3}-$ characteristic of siderite. The thin sections also iron showed sulphides - pyrite (Fig. 6D, sample K2), the density of which is $\sim 5 \mathrm{~g} / \mathrm{cm}^{3}$. A higher density can be also caused by the presence of diagenetic clay minerals, mainly illite (Fig. 8D). Finally, increase in bulk rock density is also affected by the accumulation of muscovite grains (Figs. 8C and 10D), the density of which is $2.83 \mathrm{~g} / \mathrm{cm}^{3}$.

The occurrence of diagenetic carbonate minerals, the content of which ranged from 0 to $15 \%$, and illite are the main factors determining the bulk rock density in the petrofacies A2 and B1. The factor responsible for the bulk rock density positive anomalies is more clearly visible in petrofacies B2. The accumulation of mica and illite in the micaceous sandstones and heterolithic deposits of petrofacies B2 is probably the reason for their anomalously high density, locally exceeding $2.85 \mathrm{~g} / \mathrm{cm}^{3}$. Finally, the anomalously low density, to $<2.5 \mathrm{~g} / \mathrm{cm}^{3}$, rarely observed in the petrofacies A1 and B1, is probably caused by higher porosity or by the accumulation of carbonaceous plant fragments (Figs. 7B and 10A, D).

\section{CONCLUSIONS}

The analyses compiled of lithological features of the core material, petrographical analysis of the mineral composition and geophysical features of the Dęblin Formation sandy rocks of the Korczmin IG 1 and Jarczów IG 4 boreholes allow distinction of four sub-petrofacies, which are easily detectable on gamma-ray and bulk rock density logs. The sedimentological analysis helped ndicate the probable sedimentary environment of the sandstones analysed and their characteristic features. It also enabled the recognition of lithology and rock parameters in un-cored intervals.

The sandy rocks analysed are mainly composed of lithic and sublithic arenites and wackes, with different contents of radioactive minerals, which markedly change the natural gamma-ray intensity. Positive gamma-ray anomalies (values above $60 \mathrm{API}$ ) are correlated with accumulations of mica and illite in the micaceous sandstones and heterolithic deposits of petrofacies $B$, and are characteristic for the Dęblin Formation. In petrofacies A2 some admixture of illite, mica, potassium feldspars and accessory zircon also increases the gamma-ray intensity but their content is lower than in petrofacies $B$. The presence of high-density minerals, as well as diagenetic carbonates, (especially siderite) and pyrite, are the main reason for the positive anomalies observed in the bulk rock density logs. Some primary elements in the rocks - muscovite and accessory heavy minerals - also lead to high density. The high content of diagenetic clay minerals, especially illite, detected during the SEM analysis, can also slightly increase rock density. The differences described in the mineral composition are crucial to understanding the main reasons for different geophysical measurements across the same lithology. This type of analysis can upgrade the petrophysical analysis and help to determine the sweet spots and the best intervals for hydrocarbon exploration.

Acknowledgements. We would like to thank the two anonymous reviewers, whose constructive remarks have improved and enriched this paper. 


\section{REFERENCES}

Bhattacharya, S., Doveton, J.H., Carr, T.R., Guy, W.R., Gerlach, P.M., 2005. Integrated core-log petrofacies analysis in the construction of a reservoir geomodel: a case study of a mature Mississippian carbonate reservoir using limited data. AAPG Bulletin, 89: 1257-1274

Bolesta, F., Gałązka, A., 2014. Gamma-ray log - units conversion (in Polish with English summary). Nafta-Gaz, 8: 493-501.

Botor, D., Kotarba, M., Kosakowski, P., 2002. Petroleum generation in the Carboniferous strata of the Lublin Trough (Poland): an integrated geochemical and numerical modelling approach. Organic Geochemistry, 33: 461-476.

Cant, D.J., Walker, R.G., 1978. Fluvial processes and facies sequences in the sandy braided South Saskatchewan River, Canada. Sedimentology, 25: 625-648.

De Ros, L.F., Goldberg, K., 2007. Reservoir petrofacies: a tool for quality characterization and prediction. In: AAPG, Annual Convention and Exhibition, Long Beach, Abstracts Volume: 1-7.

Elliott, T., 1986. Deltas. In: Sedimentary Environments and Facies (ed. J.D. Collinson): 155-188. Blackwell, Oxford, UK.

Fan, A., Yang, R., Lenhardt, N., Wang, M., Han, Z., Li, J., Li, Y., Zhao, Z., 2019. Cementation and porosity evolution of tight sandstone reservoirs in the Permian Sulige gas field, Ordos Basin (central China). Marine and Petroleum Geology, doi https://doi.org/10.1016/ j.marpetgeo.2019.02.010

Ingersoll, R.V., 1990. Actualistic sandstone petrofacies: discriminating modern and ancient source rocks. Geology, 18: 733-736.

Jarzyna, J., Bała, M., 2005. Relationships between petrophysical parameters of the Carboniferous clastic rocks in the Stężyca hydrocarbon deposits, Lublin Basin (in Polish with English summary). Geologia, 31: 337-355.

Jarzyna, J., Bała, M., Zorski, T., 1999. Metody geofizyki otworowej, pomiary i interpretacja (in Polish). Uczelniane Wydawnictwa Naukowo-Dydaktyczne AGH.

Karnkowski, P.H., 2007. Petroleum provinces in Poland (in Polish with English summary). Przeglad Geologiczny, 55: 1061-1067.

Kmiecik, H., 1995. Microflora. Prace Państwowego Instytutu Geologicznego, 148: 70-85

Kozłowska, A., 2003. The influence of diagenesis on the reservoir quality of the upper Carboniferous sandstones in the region between Warsaw and Dęblin (central Poland) (in Polish with English summary). Przegląd Geologiczny, 51: 777-782.

Kozłowska, A., 2004. Diagenesis of the Upper Carboniferous sandstones occurring at the border of the Lublin Trough and the Warsaw Block (in Polish with English summary). Biuletyn Państwowego Instytutu Geologicznego, 411: 5-85.

Kozłowska, A., 2009. Diagenetic processes affecting pore space in Carboniferous sandstones of the Lublin region (in Polish with English summary). Przeglad Geologiczny, 57: 335-342.

Kozłowska, A., 2011. Clay minerals in the Carboniferous sandstones of the southeastern part of the Lublin Basin as paleotemperature indicators of diagenesis (in Polish with English summary). Biuletyn Państwowego Instytutu Geologicznego, 444: 99-111.

Large, E., Ingersoll, R.V., 1997. Miocene and Pliocene sandstone petrofacies of the northern Albuquerque Basin, New Mexico, and implications for the evolution of the Rio Grande Rift. Journal of Sedimentary Research, 67: 462-468.

Liu, L., Zhang, J., Wang, J., Li, C., Yu, J., Zhang, G., Fan, Z., Wei, Z., Sun, Z., Xue, X., Yu, T., Wang, G., 2015. Geostatistical modeling for fine reservoir description of Wei2 block of Weicheng oilfield, Dongpu depression, China. Arabian Journal of Geosciences, 8: 9101-9115.

Miall, A.D., 1996. The Geology of Fluvial Deposits. Sedimentary Facies, Basin Analysis and Petroleum Geology. Springer, Berlin, Heidelberg.
Musiał, Ł., Tabor, M., 1979. Stratygrafia karbonu Lubelskiego Zagłębia Węglowego na podstawie makrofauny (in Polish). In Stratygrafia Węglonośnej Formacji Karbońskiej w Polsce (ed. T. Migier): 35-43. II Sympozjum, 4-5 maja 1977, Sosnowiec.

Musiał, Ł., Tabor, M., 1988. Macrofaunal stratigraphy of the Carboniferous (in Polish with English summary). Prace Instytutu Geologicznego, 122: 88-122.

Musiał, Ł., Tabor, M., 1995. Macrofauna. Prace Państwowego Instytutu Geologicznego, 148: 23-44.

Narkiewicz, M., 2007. Development and inversion of Devonian and Carboniferous basins in the eastern part of the Variscan foreland (Poland). Geological Quarterly, 51 (3): 231-256.

Pettijohn, F.J., Potter, P.E., Siever, R., 1972. Sand and Sandstone. Springer-Verlag, New York.

Porzycki, J., 1979. Litostratygrafia osadów karbonu Lubelskiego Zagłębia Węglowego (in Polish). In: Stratygrafia Węglonośnej Formacji w Polsce (ed. T. Migier): 19-27. II Sympozjum, 4-5 maja 1977, Sosnowiec.

Porzycki, J., 1988. The lithologic and sedimentologic characteristic of Carboniferous deposits (in Polish with English summary). Prace Instytutu Geologicznego, 122: 40-76.

Porzycki, J., Zdanowski, A., 1995. Lithostratigraphy and sedimentologic-paleogeographic development. Southeastern Poland (Lublin Carboniferous Basin). Prace Państwowego Instytutu Geologicznego, 148: 102-109.

Rider, M., 2002. Geological Interpretation of Well Logs. Rider-French Consulting Ltd.

Serra, O., 1984. Fundamentals of Well-log Interpretation: The Interpretation of Logging Data, Vol. 2. Elsevier Science Limited.

Skompski, S., 1986. Upper Viséan calcareous algae from the Lublin Coal Basin. Acta Geologica Polonica, 36: 151-185.

Skompski, S., 1996. Stratigraphic position and facies significance of the limestone bands in the subsurface Carboniferous succession of the Lublin Upland. Acta Geologica Polonica, 46: 171-268.

Skompski, S., 1998. Regional and global chronostratigraphic correlation levels in the late Viséan to a Westphalian succession of the Lublin Basin (SE Poland). Geological Quarterly, 42 (2): $121-130$.

Soboń-Podgórska, J. Tomaś, A., 1995. Chrono- and biostratigraphy. Microfauna. Prace Państwowego Instytutu Geologicznego, 148: 44-47.

Szewczyk, J., 2000. Bulk density and synthetic density logs (in Polish with English summary). Biuletyn Państwowego Instytutu Geologicznego, 392: 153-172.

Waksmundzka, M.I., 1998. Depositional architecture of the Lublin Coal Basin (in Polish with English summary). Prace Państwowego Instytutu Geologicznego, 165: 89-100.

Waksmundzka, M.I., 2010. Sequence stratigraphy of Carboniferous paralic deposits in the Lublin Basin (SE Poland). Acta Geologica Polonica, 60: 557-597.

Waksmundzka, M.I., 2012. Braided-river and hyperconcentrated-flow deposits from the Carboniferous of the Lublin Basin (SE Poland) - a sedimentological study of core data. Geologos, 18: 135-161.

Waksmundzka, M.I., 2013. Carboniferous coarsening-upward and non-gradational cyclothems in the Lublin Basin (SE Poland): palaeoclimatic implications. Geological Society Special Publications 376.1: 141-175.

Yang, R., Fan, A., Van Loon, A. J., Han, Z., Wang, X., 2014 Depositional and diagenetic controls on sandstone reservoirs with low porosity and low permeability in the Eastern Sulige gas field, China. Acta Geologica Sinica-English Edition, 88: 1513-1534. 
Zieliński, T., 1998. Litofacjalna identyfikacja osadów rzecznych (in Polish). In: Struktury sedymentacyjne i postsedymentacyjne w osadach czwartorzędowych i ich wartość interpretacyjna (ed. J. Mycielska-Dowgiałło). Wydawnictwa Uniwersytetu Warszawskiego, Warszawa: 195-260.

Żelaźniewicz, A., Aleksandrowski, P., Buła, Z., Karnkowski, P.H., Konon, A., Oszczypko, N., Ślączka, A., Żaba, J., Żytko, K., 2011. Pasmo fałdowe Gór Świętokrzyskich i jednostki tektoniczne Polski południowo-wschodniej (in Polish). In:
Regionalizacja tektoniczna Polski (ed. A. Żelaźniewicz): 25-28. Komitet Nauk Geologicznych PAN.

Żelichowski, A.M. 1964. Problemy litologii i sedymentologii dolnego karbonu w Polsce (in Polish). Kwartalnik Geologiczny, 8 (3): 524-541.

Żelichowski, A.M., 1972. Evolution of the geological structure of the area between the Holy Cross Mountains and the Bug river. Tectonic research in Poland (in Polish with English summary). Biuletyn Instytutu Geologicznego, 263: 5-97. 